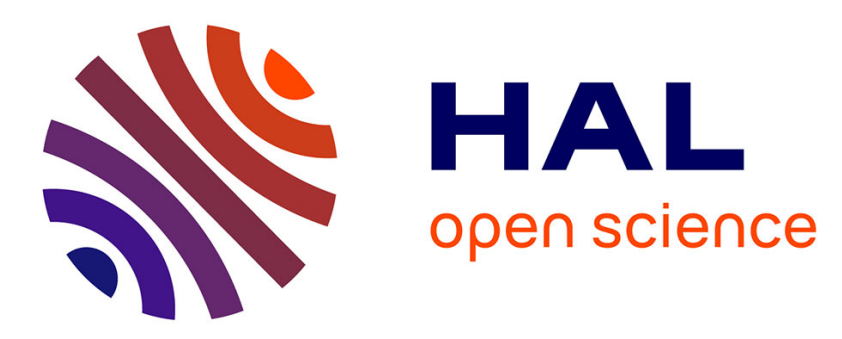

\title{
Rare Earth Elements as tracers of active colloidal organic matter composition
}

Charlotte Catrouillet, Helene Guenet, Anne-Catherine Pierson-Wickmann, Aline Dia, Martine Bouhnik-Le Coz, Sarah Deville, Quentin Lenne, Yasushi Suko, Mélanie Davranche

\section{To cite this version:}

Charlotte Catrouillet, Helene Guenet, Anne-Catherine Pierson-Wickmann, Aline Dia, Martine Bouhnik-Le Coz, et al.. Rare Earth Elements as tracers of active colloidal organic matter composition. Environmental Chemistry, 2020, 17 (2), pp.133-139. 10.1071/EN19159 . hal-02348896

\section{HAL Id: hal-02348896 https://hal.science/hal-02348896}

Submitted on 29 Jan 2021

HAL is a multi-disciplinary open access archive for the deposit and dissemination of scientific research documents, whether they are published or not. The documents may come from teaching and research institutions in France or abroad, or from public or private research centers.
L'archive ouverte pluridisciplinaire HAL, est destinée au dépôt et à la diffusion de documents scientifiques de niveau recherche, publiés ou non, émanant des établissements d'enseignement et de recherche français ou étrangers, des laboratoires publics ou privés. 


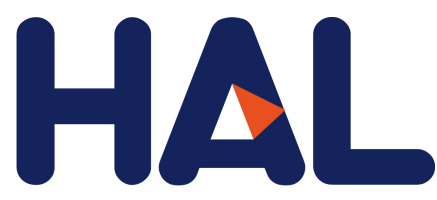

archives-ouvertes

\section{Rare Earth Elements as tracers of active colloidal organic matter composition}

Charlotte Catrouillet, Helene Guenet, Anne-Catherine Pierson-Wickmann, Aline Dia, Martine Bouhnik-Le Coz, Sarah Deville, Quentin Lenne, Yasushi Suko, Mélanie Davranche

\section{To cite this version:}

Charlotte Catrouillet, Helene Guenet, Anne-Catherine Pierson-Wickmann, Aline Dia, Martine Bouhnik-Le Coz, et al.. Rare Earth Elements as tracers of active colloidal organic matter composition. Environmental Chemistry, CSIRO Publishing, 2020, 17 (2), pp.133-139. 10.1071/EN19159 . hal-02348896

\section{HAL Id: hal-02348896 \\ https://hal.archives-ouvertes.fr/hal-02348896}

Submitted on 29 Jan 2021

HAL is a multi-disciplinary open access archive for the deposit and dissemination of scientific research documents, whether they are published or not. The documents may come from teaching and research institutions in France or abroad, or from public or private research centers.
L'archive ouverte pluridisciplinaire HAL, est destinée au dépôt et à la diffusion de documents scientifiques de niveau recherche, publiés ou non, émanant des établissements d'enseignement et de recherche français ou étrangers, des laboratoires publics ou privés. 


\title{
Rare earth elements as tracers of active colloidal organic matter composition
}

\author{
Charlotte Catrouillet, ${ }^{(D)} \mathrm{A}, \mathrm{B}$ Héléne Guenet, ${ }^{\mathrm{A}}$ \\ Anne-Catherine Pierson-Wickmann, ${ }^{\mathrm{A}}$ Aline Dia, ${ }^{\mathrm{A}}$ Martine Bouhnik LeCoz, ${ }^{\mathrm{A}}$ \\ Sarah Deville, ${ }^{\mathrm{A}}$ Quentin Lenne, ${ }^{\mathrm{A}}$ Yasushi Suko ${ }^{\mathrm{A}}$ and Mélanie Davranche ${ }^{\mathrm{A}}$

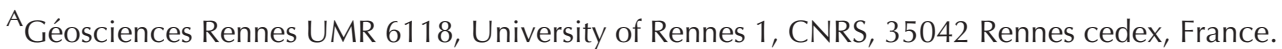 \\ ${ }^{\mathrm{B}}$ Corresponding author. Email: charlotte.catrouillet@univ-rennes1.fr
}

Environmental context. The origin of organic matter at Earth's continental surface can be either terrestrial or microbial, and its precise composition can influence its reactivity towards metals. We investigated the potential of rare earth elements to fingerprint the origin of various organic matters through their reactivity and composition. The rare earth element patterns can be useful tools to determine the reactivity and also pristine source of natural organic matter.

\begin{abstract}
Rare earth elements (REEs) have been shown to be efficient tracers of the functional sites and/or complexes formed on humic molecules. In the present study, we test the potential of REEs to be used as tracers of the sources of humic substances (HSs). Three types of organic matter $(\mathrm{OM})$ of terrestrial and microbiological origin were tested. The experiments of REEs binding to the HSs were combined with size-fractionation experiments. The REE patterns were the most fractionated in the $<10 \mathrm{kDa}$ fraction. For Leonardite humic acid (LHA) and Aldrich humic acid (AHA), the REE patterns were consistent with the REEs binding to strong but low density sites for a low REE/C loading. By contrast, for Pony Lake fulvic acid (PLFA), the REE pattern was similar to the REE pattern developed onto a bacteria cell surface and was attributed to the REEs binding to phosphate surface sites. Fluorescence and elemental analysis of PLFA showed that the $<10 \mathrm{kDa}$ fraction was the fraction with the stronger microbiological character, which suggested the REEs were probably bound to PLFA through REE-phosphate complexes. Such results therefore provide a new possibility for the use of REEs to assess an OM source without the need to perform numerous or complex analytical methodologies.
\end{abstract}

Additional keywords: organic matter, patterns, rare earth elements, size fractionation, tracer.

Received 29 May 2019, accepted 16 October 2019, published online 4 December 2019

\section{Introduction}

The rare earth element (REE) pattern is able to fingerprint a sorption mechanism through the establishment of REE interactions with mineral or organic surfaces (Koeppenkastrop and De Carlo 1992; Quinn et al. 2006; Pourret et al. 2007; Marsac et al. 2010; Davranche et al. 2011). The REE pattern provides a signature of the activated functional groups involved in the binding mechanisms of the REEs on a solid surface. This tracing potential occurs thanks to the chemical property coherence among all of the 14 members of the REEs group (La, Ce, Pr, Nd, Sm, Eu, Gd, Tb, Dy, Ho, Er, Tm, Yb and Lu).

Several authors demonstrated that REE patterns are controlled by their binding with carboxylic, phenolic and multidentate sites developed on the colloidal humic molecules. At low REE loading, REEs are bound to strong affinity groups but low density groups such as phenolic or chelating functional sites (Pourret et al. 2008; Kautenburger et al. 2014; Marsac et al. 2015). The resulting REE pattern exhibits a regular REE enrichment from $\mathrm{La}$ to $\mathrm{Lu}$. This REE pattern is quite similar to that developed by the REEs binding with catechol and ethylenediamineetraacetic acid (EDTA) (Marsac et al. 2010; Marsac et al. 2011; Davranche et al. 2015; Marsac et al. 2015). At high
REE loading, REEs are mainly bound to low affinity but high density sites such as carboxylic groups (as monodendate or bidendate complexes). The resulting REE pattern exhibits a middle REE (MREE) enrichment, which results in a MREE downward concavity on the REE pattern. This pattern shape is identical to that of an REE-acetate complex (Tang and Johannesson 2003; Pourret et al. 2007; Marsac et al. 2010; Davranche et al. 2015). Such results were deduced from experimental and modelling studies (Sonke and Salters 2006; Pourret et al. 2007; Marsac et al. 2010) and were confirmed by extended $\mathrm{X}$-ray absorption fine structure (EXAFS) analyses, a technique that provides the atomic environment of the REE (Marsac et al. 2015). Kautenburger et al. (2014), by blocking the phenolic or carboxylic groups of humic acid (HA), demonstrated that the REE binding mechanisms varied depending on the type of blocked groups. Marsac and co-workers demonstrated that HA sites blocked by ions such as $\mathrm{Fe}^{3+}$ and $\mathrm{Al}^{3+}$ affect the REE pattern (Marsac et al. 2012; Marsac et al. 2013). The REE pattern is thus controlled by the heterogeneity, density and availability of the sites developed on the colloidal humic molecules. Such heterogeneity and density variations result themselves from the conformation, composition and source of 
the organic molecules. Tadini et al. (2013) demonstrated that the binding capacity of $\mathrm{Cu}^{\mathrm{II}}$ and $\mathrm{Ni}^{\mathrm{II}}$ by organic matter $(\mathrm{OM})$ from urban areas (areas with high urbanisation rates with $\sim 415000$ inhabitants) was much higher than that from agricultural zones. This discrepancy was attributed to the lower density of binding sites for the agricultural OM. Gangloff et al. (2014) used infrared analysis on soil OM to show that OM aromaticity variations might be related to the variations of the surface reactivity. They demonstrated that heavy REE (HREE), as compared with light REE (LREE), were bound to more aromatic functional groups of $\mathrm{OM}$ in the deep soil horizon. Other authors showed that heating increased the aromaticity of soil OM, which increased the reactivity of $\mathrm{OM}$ for $\mathrm{Cu}$ (Cornu et al. 2011). Nakada et al. (2016) studied the behaviour of REEs during the maturation of organic compounds and showed that the decarboxylation resulting from the heating process is associated with a strong REE release, the disappearance of the MREE downward concavity and an REE tetrad effect on the REE patterns. These variations were attributed to the decrease of the density of the carboxylic groups and the REE sorption to form an outer-sphere complex upon heating (Nakada et al. 2016).

With regards to the REE pattern sensitivity towards the OM site heterogeneity and density, it can be hypothesised that the REE pattern could also fingerprint the composition of the active natural OM involved in metal binding. This work is therefore dedicated to the evaluation of the potential of the REE pattern to be used as a tracer of the 'composition' (in every sense) of the active natural $\mathrm{OM}$ involved in metal binding. For this purpose, complexation experiments of the whole REE group with wellstudied humic substances (HSs) of variable compositions were performed. Leonardite humic acid (LHA), Pony Lake fulvic acid (PLFA) and the non-purified Aldrich humic acid (AHA) were chosen. To identify a potential link between the REE patterns and the active OM composition: (i) suspensions underwent size fractionation; (ii) REE patterns were determined in each fraction; and (iii) OMs in each fraction were characterised by three-dimensional excitation emission matrix (3D-EEM) fluorescence spectroscopy.

\section{Experimental}

All aqueous solutions were prepared with analytical grade Milli-Q ${ }^{\circledR}$ water (Millipore). The REE solutions were prepared with a nitrate REE standard $\left(10 \mathrm{mg} \mathrm{L}^{-1}\right.$, Accu Trace ${ }^{\mathrm{TM}}$ Reference Standard). Acid and base solutions of $\mathrm{HCl}, \mathrm{HNO}_{3}$ and $\mathrm{NaOH}$, all sub-boiling ultrapure grade, were provided by Fisher Chemical, Merck and VWR respectively. Used plastic labware were soaked in $10 \% \mathrm{HNO}_{3}$ and then rinsed with ultra-pure water (MilliQ system) twice overnight.

Humic substances were LHA, PLFA and AHA. Leonardite HA is derived from a low-grade coal and produced by natural oxidation of exposed lignite (IHSS 2019). Pony Lake fulvic acid, an International Humic Substance Society (IHSS) reference standard, is a microbially-derived fulvic acid from a purely microbially-based aquatic ecosystem (IHSS 2019). Aldrich HA is a terrestrial peat-derived humic material composed of larger molecules than typical aquatic HA. Residual metals are present in purified OM. As explained by Marsac et al. (2010), these metals are so strongly bound to the OM that purification processes (use of strong acids and chelating resins according to the IHSS procedure) fail to remove these metals. Therefore, it is possible to assume that the functional groups bound to these metals are not available to any other cation. The effect of these blocked sites (and the metals blocking them) can be neglected.
After acidic digestion, blank REE concentrations occurring in each HS were determined by inductively coupled plasma-mass spectrometry (ICP-MS). The total REE concentrations ( $\Sigma$ REE) were $1.2 \times 10^{-8}, 5.6 \times 10^{-8}$ and $5.5 \times 10^{-8} \mathrm{M}$ for LHA, PLFA and AHA respectively, in our experimental conditions (see Supplementary Material for the single REE concentrations).

\section{Binding experiments of REEs with humic substances}

To investigate the binding of the REEs with organic matter, batch experiments were conducted with the above-mentioned three types of humic substances. Experiments were conducted at low REE loading conditions to be able to observe REE binding with strong sites occurring at a low density (e.g. chelates or P-containing sites). Experiments were also conducted at a relatively low $\mathrm{pH}$ value $(\mathrm{pH}=4)$, which favoured $\mathrm{REE}$ binding to the strong sites over the abundant but weaker sites (e.g. mono-carboxylic groups) (Marsac et al. 2010). All the REE complexation experiments with HSs were conducted in triplicate in $1000-\mathrm{mL}$ polypropylene containers. The REE binding experiments were performed with an expected final REE/C ratio of $4 \times 10^{-5} \mathrm{~mol} \mathrm{~mol}^{-1}$ (dissolved organic carbon $\left.(\mathrm{DOC})=19-24 \mathrm{mg} \mathrm{L}^{-1}\right)$. The $\mathrm{pH}$ was fixed at $\mathrm{pH} 4$ with $\mathrm{HCl}$ and $\mathrm{NaOH}$ and kept constant until equilibrium with a multiparameter Consort C830 analyser combined with an electrode from Bioblock Scientific (combined Mettler InLab electrode). The accuracy of the $\mathrm{pH}$ measurements was $\pm 0.05 \mathrm{pH}$ units. Such experimental conditions were thus selected to (i) limit REEcarbonates and REE-OH complexes formation and (ii) allow the observation of REE complexation to the HS strong sites through the REE pattern variations. The ionic strength was fixed at $0.001 \mathrm{M}$ with $\mathrm{NaCl}$ as a background electrolyte. Experimental solutions were stirred for $48 \mathrm{~h}$ to reach equilibrium (Pourret et al. 2007). Then, the suspensions were filtrated at $0.2 \mu \mathrm{m}$ using acetate cellulose filters (Sartorius). An aliquot of $15 \mathrm{~mL}$ was sampled for 3D-EEM fluorescence spectroscopy, DOC and REE analysis. The remaining fractions were ultrafiltrated at $10 \mathrm{kDa}$ using a Labscale TFF system equipped with a Pellicon XL membrane and $15 \mathrm{~mL}$ of the fractions $<10 \mathrm{kDa}$ and $>10 \mathrm{kDa}$ were sampled for 3D-EEM fluorescence spectroscopy, DOC and REE analysis.

\section{Solution analysis}

All the measurements were performed at Géosciences Rennes (University of Rennes 1, France). The DOC concentrations were measured using a total organic carbon analyser (Shimadzu TOC-V CSH). The accuracy of the DOC measurements was estimated at $\pm 5 \%$ for all samples using a standard solution of potassium hydrogen phtalate. The REE concentrations were determined by ICP-MS using an Agilent Technologies 7700 ICP$\mathrm{MS}$ system. Prior to the analyses, samples with DOC $>20 \mathrm{mg} \mathrm{L}^{-1}$ were digested twice with $14.6 \mathrm{M} \mathrm{HNO}_{3}$ and $\mathrm{H}_{2} \mathrm{O}_{2}$ (ultra-pure grade) at $90{ }^{\circ} \mathrm{C}$, evaporated to complete dryness and finally resolubilised with $\mathrm{HNO}_{3}$ at $0.37 \mathrm{M}$ to avoid any interference with DOC during analysis. The detection limit of ICP-MS analysis for REE varied from 0.15 to $0.77 \mathrm{ng} \mathrm{\textrm {L } ^ { - 1 }}$.

\section{Humic substances characterisation}

The fractions below $0.2 \mu \mathrm{m}$ and $10 \mathrm{kDa}$ were analysed using a spectrofluorometer (Perkin-Elmer LS 45) in a 10 -mm quartz cuvette (Ecole Nationale Supérieure de Chimie de Rennes (ENSCR), France). The 3D-EEM fluorescence spectra were acquired by collecting individual emission spectra $(290-600 \mathrm{~nm})$ over a range of excitation wavelengths ranging from 240 to 
Table 1. Elemental composition of LHA, PLFA (IHSS 2019) and AHA (Kim et al. 1990)

\begin{tabular}{lcccrrr}
\hline & Ash\% & $\mathrm{C} \%$ & $\mathrm{H} \%$ & $\mathrm{O} \%$ & $\mathrm{~N} \%$ & $\mathrm{~S} \%$ \\
\hline LHA & 2.58 & 63.81 & 3.70 & 31.27 & 0.76 & 1.23 \\
PLFA & 1.25 & 52.47 & 5.39 & 31.38 & 6.51 & 3.03 \\
AHA & 3.35 & 55.23 & 4.48 & 37.64 & 0.32 & 2.33 \\
\hline
\end{tabular}

$550 \mathrm{~nm}$, with an increment of $5 \mathrm{~nm}$, at a scan speed of $1500 \mathrm{~nm} \mathrm{~min}{ }^{-1}$. The slits were set to $10 \mathrm{~nm}$ for both excitation and emission monochromators. Three indexes were calculated to characterise the OM. The fluorescence index (FI) was the ratio of the emission intensity at $\lambda_{\mathrm{Em}} 450 \mathrm{~nm}$ to that of $\lambda_{\mathrm{Em}}$ $500 \mathrm{~nm}$ using a fixed excitation at $\lambda_{\mathrm{Ex}} 370 \mathrm{~nm}$ (McKnight et al. 2001). The biological index (BIX) was calculated from the ratio of emission intensities at $\lambda_{\mathrm{Em}} 380 \mathrm{~nm}$ and $\lambda_{\mathrm{Em}} 430 \mathrm{~nm}$ using a fixed excitation $\lambda_{\mathrm{Ex}} 310 \mathrm{~nm}$ (Huguet et al. 2009). Finally, the fluorescence humification index (HIX) was calculated as the ratio of $\lambda_{\mathrm{Em}} 435-480 \mathrm{~nm}$ divided by $\lambda_{\mathrm{Em}} 300-345 \mathrm{~nm}$ at a fixed excitation of $254 \mathrm{~nm}$ (Zsolnay et al. 1999). The elemental composition of the different HSs is provided in Table 1.

\section{Results}

Organic matter composition

Indexes calculated from the fluorescence spectral analysis are plotted in Fig. 1 for each fraction and HS. The FI varied strongly with the HS but weakly between fractions. The FI indicated a terrestrial origin for LHA and AHA (FI < 1.24) (McKnight et al. 2001) and a larger contribution of microbially-derived material for PLFA (FI > 1.6). The BIX, which presented lower values for LHA (0.36) and AHA (0.32) than for PLFA (0.66), confirmed a large proportion of predominantly microbially-derived organic matter for PLFA. A slight but significant BIX increase in the $<10 \mathrm{kDa}$ fraction of LHA and PLFA indicated that the smallest organic molecules had a more pronounced biological character. Finally, HIX $>5$ demonstrated the humic character (old, transformed and more aromatic OM) of each HS, which was higher for LHA and AHA (HIX > 20) than for PLFA (HIX 9). The highest HIX were obtained for LHA and PLFA in the $0.2 \mu \mathrm{m}-10 \mathrm{kDa}$ fraction compared with the $<10 \mathrm{kDa}$ fraction for AHA. The most humic molecules occurred in the $0.2 \mu \mathrm{m}-10 \mathrm{kDa}$ fraction for PLFA and LHA although the $<10 \mathrm{kDa}$ fraction was composed of biological and humic organic molecules. Pony Lake FA differed strongly from LHA and AHA with regard to its microbial source, and AHA was most humic with the highest amount of small humic molecules.

\section{Rare earth elements and organic carbon $\left(C_{\text {org }}\right)$ distribution}

The proportions of organic carbon $\left(\mathrm{C}_{\mathrm{org}}\right)$ and REE as compared with the total concentrations of $\mathrm{C}_{\text {org }}$ and REE for each sizefraction and HS are reported in Fig. 2. Organic carbon distribution varied with the size fraction and HS. The $0.2 \mu \mathrm{m}-10 \mathrm{kDa}$ fraction was the most enriched in $\mathrm{C}_{\text {org }}$ for all HSs, with $\mathrm{C}_{\text {org }}$ proportions decreasing in the order of LHA $(65 \%)>$ PLFA $(61.5 \%)>$ AHA $(40.5 \%)$. The highest $\mathrm{C}_{\text {org }}$ proportion obtained for LHA was explained by the LHA size, which varied between 30 to $20 \mathrm{kDa}$ (Vermeer et al. 1998). For the $>0.2 \mu \mathrm{m}$ fraction, the amount of $\mathrm{C}_{\text {org }}$ varied with the HS. Aldrich HA displayed the highest $\mathrm{C}_{\text {org }}$ proportion $(40.2 \%$ ), which was consistent with a HS composition that contained humin, ash, and humic and fulvic

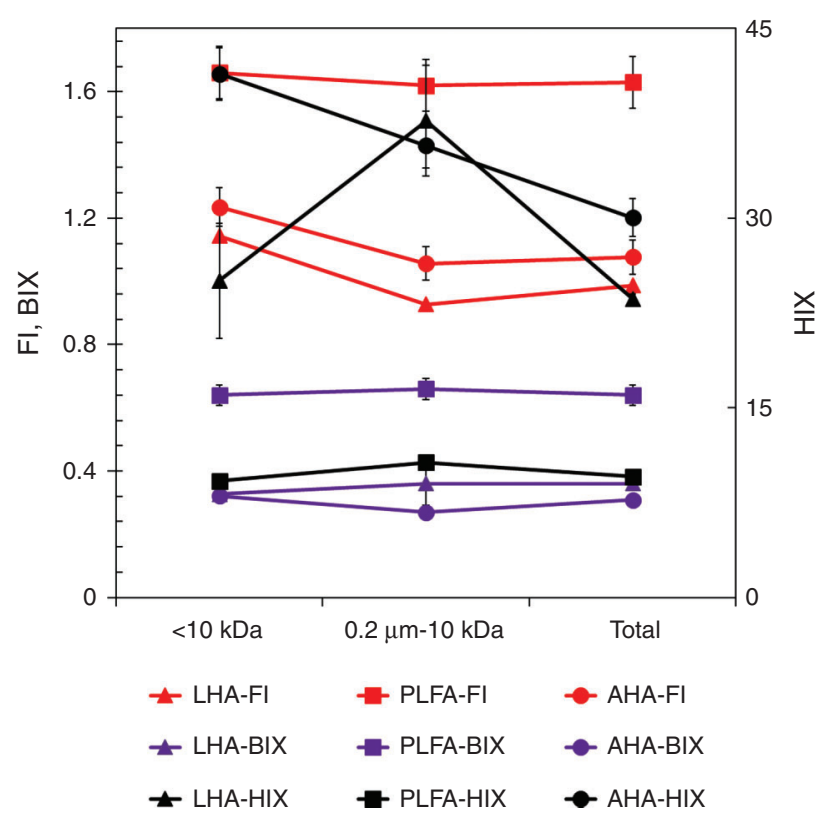

Fig. 1. Evolution of the FI, BIX and HIX in each fraction for LHA, PLFA and AHA.

acids as well. Aldrich HA was thus more polydisperse than LHA and PLFA. For PLFA, this fraction represented $12.4 \%$, which suggested that PLFA contained a few large molecules and/or that precipitation was limited at $\mathrm{pH} 4$. For LHA, $24 \%$ of $\mathrm{C}_{\text {org }}$ was in the $>0.2 \mu \mathrm{m}$ fraction, which indicated the presence of LHA precipitates in our experimental conditions. For the $<10 \mathrm{kDa}$ fraction, the highest $\mathrm{C}_{\text {org }}$ proportion $(28.2 \%)$ was obtained for PLFA, which was consistent with (i) the generally smaller size of FA as compared with HA and (ii) previous studies demonstrating that PLFA was enriched in labile (bioavailable) molecules (D'Andrilli et al. 2013; D'Andrilli et al. 2015). In this fraction, the smallest $\mathrm{C}_{\text {org }}$ proportion was obtained for LHA (4.6\%).

Accordingly, REE distributions varied with the fractions and the HS. As observed for $\mathrm{C}_{\mathrm{org}}$, the $0.2 \mu \mathrm{m}-10 \mathrm{kDa}$ fraction was the most enriched in REE for LHA and PLFA. For the $>0.2 \mu \mathrm{m}$ fraction, as expected regarding the $\mathrm{C}_{\text {org }}$ amount, AHA exhibited the highest REE proportions ( $50 \%$ of REE) with a high REE/C ratio (close to the initial ratio $=4 \times 10^{-5}$, Fig. 3), which suggested the REE binding to the large particles of AHA. For PLFA, $22 \%$ of REEs occurred in the $>0.2 \mu \mathrm{m}$ fraction, although this fraction contained the smallest proportion of $\mathrm{C}_{\text {org }}$. This corresponded to the highest REE/C ratio $\left(3.1 \times 10^{-5}\right)$ for PLFA. This result suggested that despite their small proportions, these particles were particularly complexing towards REE. For LHA, $49 \%$ of REEs were in the $>0.2 \mu \mathrm{m}$ fraction, which corresponded to a REE/C ratio approximately half $\left(2.1 \times 10^{-5}\right)$ that of the initial ratio $\left(4 \times 10^{-5}\right)$. The lowest $\mathrm{REE} / \mathrm{C}$ ratios were 

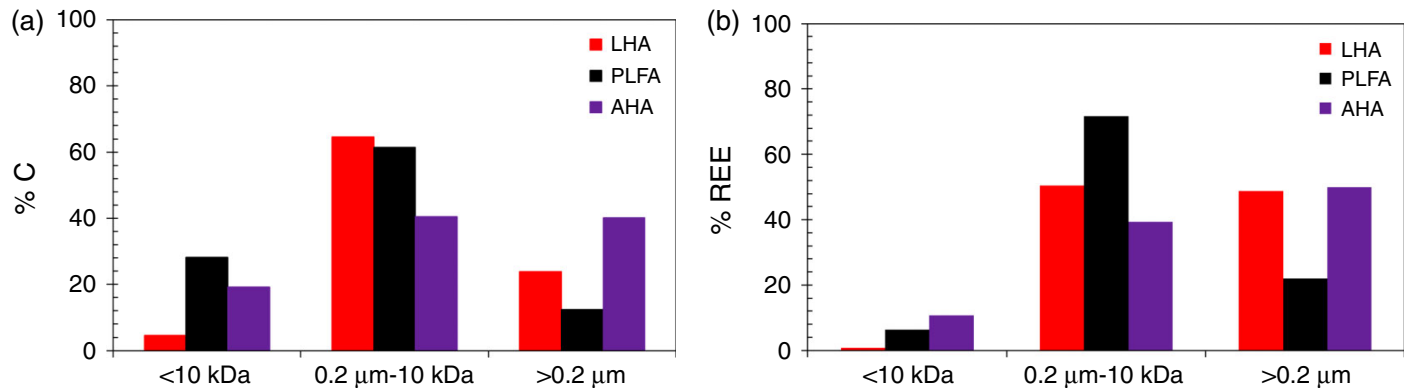

Fig. 2. (a) $\mathrm{C}_{\text {org }}$ and (b) REE proportions relative to the size fractions for LHA, PLFA and AHA.

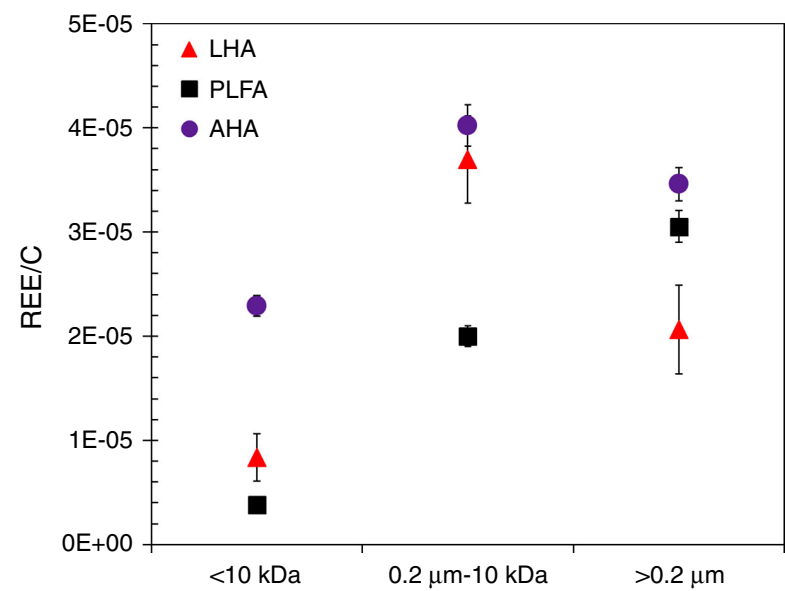

Fig. 3. REE/C ratio $\left(\mathrm{mol} \mathrm{mol}^{-1}\right)$ evolution versus the size fractions for LHA, PLFA and AHA.

obtained for the $<10 \mathrm{kDa}$ fraction whatever the considered HS ( $1 \%, 6 \%$ and $11 \%$ of the REE for LHA, PLFA and AHA respectively). Note that modelling calculations using Model VI (Marsac et al. 2011) showed that more than $99 \%$ of REEs were complexed to HS, without formation of REE-carbonate complexes in solution, as confirmed by Pourret et al. (2007). We can therefore consider that in the $<10 \mathrm{kDa}$ fraction, REEs are mostly complexed to HS and the rest is present as free ions (e.g. $\mathrm{La}^{3+}$ ).

The evolution of the $\mathrm{REE} / \mathrm{C}$ ratios for each HS in each fraction is reported in Fig. 3. The ratios varied differently according to the HS. For LHA, the highest ratio was obtained for the $0.2 \mu \mathrm{m}-10 \mathrm{kDa}$ fraction, suggesting that the $0.2 \mu \mathrm{m}$ $10 \mathrm{kDa}$ fraction contained the most REE complexing molecules, which is consistent with the LHA size that is expected to be $>20 \mathrm{kDa}$ (Vermeer et al. 1998). The smallest ratio obtained for the $>0.2 \mu \mathrm{m}$ and $<10 \mathrm{kDa}$ fractions suggested a weaker REE binding capacity of the largest and smallest LHA organic molecules. A similar trend was observed for AHA. By contrast, the $\mathrm{REE} / \mathrm{C}$ ratio of PFLA decreased regularly from the $>0.2 \mu \mathrm{m}$ to the $<10 \mathrm{kDa}$ fraction, which indicated that the REE binding capacity of the organic molecules decreased with their size.

\section{Rare earth element patterns}

Rare earth element patterns are plotted in Fig. 4 for each fraction and HS. All REE patterns in the $>10 \mathrm{kDa}$ fractions were quite flat with $\mathrm{La} / \mathrm{Sm}$ and $\mathrm{Gd} / \mathrm{Yb}$ ratios ranging from 1.39 to 0.85 imposed by the flat REE pattern of the used standard solution (Fig. 4). The La/Sm ratio $<1$ indicated a weak enrichment in LREE for all HS (Fig. 5).
For the $<10 \mathrm{kDa}$ fraction, all REE patterns exhibited a HREE enrichment from $\mathrm{Tb}$ to $\mathrm{Lu}$ with $\mathrm{Gd} / \mathrm{Yb}=0.76$ for LHA, 0.77 for AHA and 0.47 for PLFA. The enrichment was quite similar for LHA and AHA with close Gd/Yb ratios, whereas PLFA HREE enrichment was stronger, highly marked from $\mathrm{Er}$ to $\mathrm{Lu}$, as evidenced from its lower Er/Lu ratio (0.52) compared with AHA and LHA (0.80 and 0.83 respectively) (Fig. 5). The major discrepancies were obtained for the LREE and MREE. Leonardite HA and AHA REE patterns exhibited an increase from $\mathrm{La}$ to $\mathrm{Gd}$ with a $\mathrm{La} / \mathrm{Sm}$ ratio of 0.36 and 0.58 respectively, which indicated a stronger increase for LHA than for AHA. The PLFA REE pattern exhibited a low decrease from La to Gd for the fractions $>0.2 \mu \mathrm{m}$ and $0.2 \mu \mathrm{m}-10 \mathrm{kDa}$.

\section{Discussion}

For all HSs, the highest amount of REEs was found in the $0.2 \mu \mathrm{m}$ $10 \mathrm{kDa}$ and $>0.2 \mu \mathrm{m}$ fractions which displayed the highest $\mathrm{C}_{\text {org }}$ and humic character. No striking difference was observed for the flat REE patterns of the largest fractions, whereas the REE patterns in the smallest $<10 \mathrm{kDa}$ fraction showed important discrepancies. The LHA and AHA REE patterns were similar to the REE-HA patterns obtained for low REE/C loading (Marsac et al. 2011), which suggested that in the $<10 \mathrm{kDa}$ fraction, REEs were bound to HA high affinity but low density sites (phenolic and/or chelate). Despite their low concentrations in the $<10 \mathrm{kDa}$ fraction, these binding sites were sufficiently reactive to compete with the binding sites of the organic molecules of the largest fractions. For PLFA, the REE pattern exhibited a large HREE enrichment, which suggested that the binding of REE occurred through sites other than carboxylic, phenolic and chelate sites. Such HREE enrichment is similar to that observed at the surface of the bacteria Bacillus subtilis (Takahashi et al. 2005). EXAFS records provided evidence that the REE pattern at the bacteria surface was developed through the preferential HREE binding to carboxylic-phosphate complexes with the bacterial cell surface (Takahashi et al. 2010). This similarity suggested that REE should be bound to PLFA through phosphates site present on the PLFA surface. Note that the PLFA-REE pattern was closer to the REE pattern from B. subtilis (gram-positive bacteria) than Escherichia coli (gram-negative bacteria). Such a hypothesis was consistent with the PLFA composition that exhibited the highest concentration of $\mathrm{P}$ (Table 1). Moreover, the PLFA BIX for the $<10 \mathrm{kDa}$ fraction, which was the highest amongst HS samples (Fig. 1), indicated a PLFA bacterial source. However, if a similar HREE enrichment was observed between bacteria and PLFA, both patterns differed for LREE and MREE. The B. subtilis bacteria REE pattern exhibited a large MREE downward concavity consistent with the preferential MREE binding to carboxylic sites of the cell surface. Such a feature was not observed 


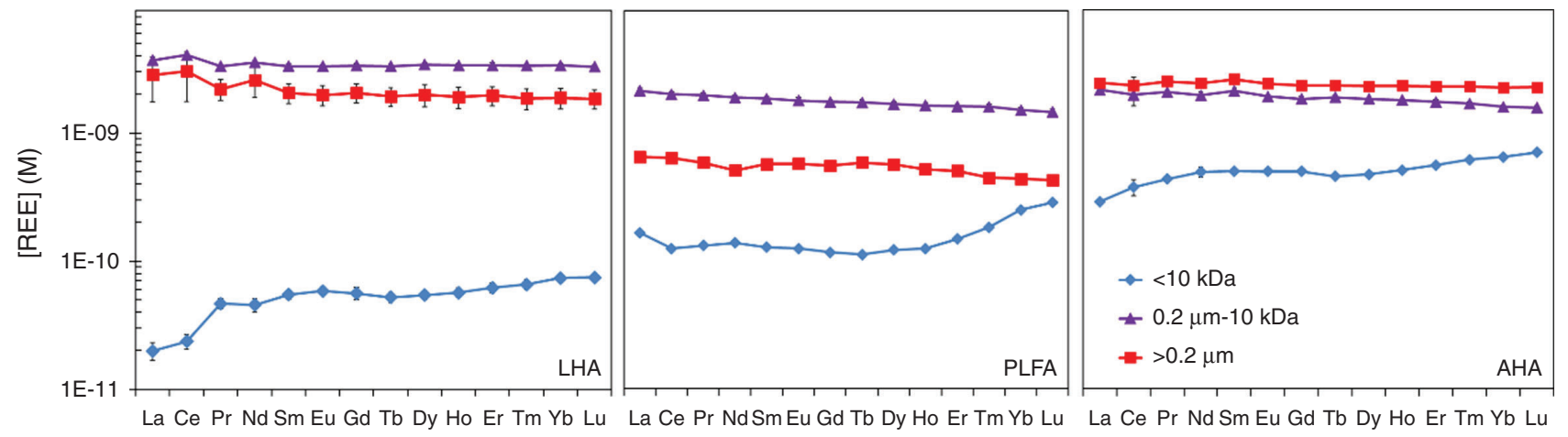

Fig. 4. REE pattern evolution of the different size fractions for LHA, PLFA and AHA. Error bars represent the standard deviation calculated for the triplicates; they are mainly within the data marker.

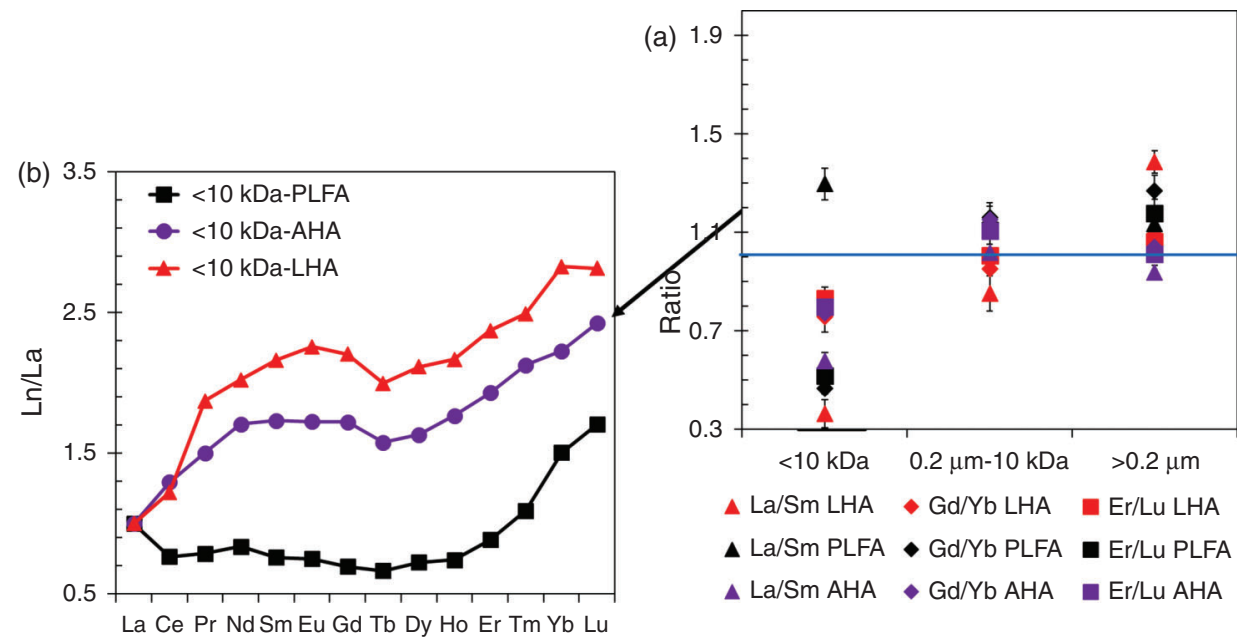

Fig. 5. (a) $\mathrm{La} / \mathrm{Sm}, \mathrm{Gd} / \mathrm{Yb}$ and $\mathrm{Er} / \mathrm{Lu}$ ratio variation versus the size fractions. (b) REE pattern normalised to La of the size fraction $<10 \mathrm{kDa}$ for LHA, PLFA and AHA. Error bars represent the standard deviation calculated for the triplicates.

on the PLFA REE pattern for the $<10 \mathrm{kDa}$ fraction, which was, by contrast, rather flat from La to Ho. This rather flat pattern can be explained by the similar affinity of the REE for the carboxylic sites from either the $<10 \mathrm{kDa}$ fraction or $>10 \mathrm{kDa}$ fraction, since both fractions were in competition for the REE binding.

As compared with PLFA, LHA and AHA were characterised by a stronger humic character and a higher $\mathrm{C}_{\text {org }}$ amount (Table 1 ) in all size fractions, except the PLFA $<10 \mathrm{kDa}$ fraction (Fig. 2). In addition, the similar LHA and AHA REE patterns, observed in the $<10 \mathrm{kDa}$ fraction, were explained by the REE binding to HA phenolic and/or chelate sites. This was confirmed for LHA by the high proportion of aromatic molecules $(58 \%)$ as compared with the carboxylic $(15 \%)$ and aliphatic $(14 \%)$ molecules (IHSS 2019). The REE pattern developed on their surface was characteristic of the REE binding to phenolic and chelate sites that gradually increased from $\mathrm{La}$ to $\mathrm{Lu}$ in the $<10 \mathrm{kDa}$ fraction, since both HAs have a terrestrial origin: low-grade coal and terrestrial peat-derived humic material for LHA and AHA respectively (Marsac et al. 2012; Davranche et al. 2013).

Pony Lake FA, composed of more aliphatic $(67 \%)$ than carboxylic (17\%) and aromatic (12\%) molecules (IHSS 2019) had a higher biological (and thus less humic) character than AHA and LHA. Pony lake FA was sampled in an algae-rich pond enriched by both sulfur-reducing bacteria and sulfur-oxidising chemiolithotroph, which explained its microbiological origin (McKnight et al. 2001). Pony Lake FA elemental composition was thus characterised by higher $\mathrm{S}, \mathrm{N}$ and $\mathrm{P}$ proportions (Table 1), which suggested the presence of proteinaceous compounds derived from microbial metabolism (D'Andrilli et al. 2013). Nitrogen and S (P was not analysed) were also measured in the $<10 \mathrm{kDa}$ fraction (Brown et al. 2004). The presence of $\mathrm{N}-, \mathrm{S}$ - and $\mathrm{P}$ - containing groups was therefore very likely in PLFA. However, according to the hard and soft acid and base principle (Pearson 1963), N- and S-, which are soft bases, bind only weakly hard cations such as REE. The occurrence of a phosphate site on PLFA was thus probably responsible for the specific REE pattern of PLFA. We can therefore conclude that the HS sources, especially terrestrial versus microbial sources, can be assessed by the combination of size fractionation and REE pattern.

\section{Conclusion}

The REE binding to three HSs of terrestrial and microbiological sources resulted in REE fractionation. This fractionation was controlled by the complexation of REE to most reactive organic molecules with a size $<10 \mathrm{kDa}$. The REE fractionation varied with the REE pristine sources (terrestrial versus microbial). Pony Lake FA exhibited a HREE enrichment in the $<10 \mathrm{kDa}$ 
fraction in response to the REE binding to PLFA phosphate sites, whereas AHA and LHA showed a rather expected REE pattern corresponding to the REE binding to HA strong sites (phenolic or chelate). Our results demonstrated that the REE pattern allows for the investigation and tracking of the OM origin in response to their binding to specific sites developed on different active organic molecules. In natural conditions, REE patterns are thus original and useful tools to fingerprint the reactivity and also pristine source of natural OM.

\section{Supplementary material}

Complementary information on the determination of the REE concentrations by ICP-MS and the REE concentrations added and present naturally in the HS are available on the Journal's website.

\section{Conflicts of interest}

The authors declare no conflicts of interest.

\section{Acknowledgements}

This research did not receive any specific funding. We thank Dr Rémi Marsac for the helpful discussions and Professor Khalil Hanna for his help using the EEM. We are grateful to the environmental geochemistry analytical platform of Geosciences Rennes (GrEEN).

\section{References}

Brown A, McKnight DM, Chin Y-P, Roberts EC, Uhle M (2004). Chemical characterization of dissolved organic material in Pony Lake, a saline coastal pond in Antarctica. Marine Chemistry 89, 327-337. doi:10.1016/ J.MARCHEM.2004.02.016

Cornu JY, Schneider A, Jezequel K, Denaix L (2011). Modelling the complexation of $\mathrm{Cd}$ in soil solution at different temperatures using the UV-absorbance of dissolved organic matter. Geoderma 162, 65-70. doi:10.1016/J.GEODERMA.2011.01.005

D’Andrilli J, Foreman CM, Marshall AG, McKnight DM (2013). Characterization of IHSS Pony Lake fulvic acid dissolved organic matter by electrospray ionization Fourier transform ion cyclotron resonance mass spectrometry and fluorescence spectroscopy. Organic Geochemistry 65, 19-28. doi:10.1016/J.ORGGEOCHEM.2013.09.013

D'Andrilli J, Cooper WT, Foreman CM, Marshall AG (2015). An ultrahighresolution mass spectrometry index to estimate natural organic matter lability. Rapid Communications in Mass Spectrometry 29, 2385-2401. doi:10.1002/RCM.7400

Davranche M, Grybos M, Gruau G, Pédrot M, Dia A, Marsac R (2011). Rare earth element patterns: A tool for identifying trace metal sources during wetland soil reduction. Chemical Geology 284, 127-137. doi:10.1016/ J.CHEMGEO.2011.02.014

Davranche M, Dia A, Fakih M, Nowack B, Gruau G, Ona-nguema G, Petitjean P, Martin S, Hochreutener R (2013). Organic matter control on the reactivity of $\mathrm{Fe}(\mathrm{III})$-oxyhydroxides and associated As in wetland soils: A kinetic modeling study. Chemical Geology 335, 24-35. doi:10. 1016/J.CHEMGEO.2012.10.040

Davranche M, Gruau G, Dia A, Marsac R, Pédrot M, Pourret O (2015). Biogeochemical Factors Affecting Rare Earth Element Distribution in Shallow Wetland Groundwater. Aquatic Geochemistry 21, 197-215. doi:10.1007/S10498-014-9247-6

Gangloff S, Stille P, Pierret M-C, Weber T, Chabaux F (2014). Characterization and evolution of dissolved organic matter in acidic forest soil and its impact on the mobility of major and trace elements (case of the Strengbach watershed). Geochimica et Cosmochimica Acta 130, 21-41. doi:10.1016/J.GCA.2013.12.033

Huguet A, Vacher L, Relexans S, Saubusse S, Froidefond JM, Parlanti E (2009). Properties of fluorescent dissolved organic matter in the Gironde Estuary. Organic Geochemistry 40, 706-719. doi:10.1016/ J.ORGGEOCHEM.2009.03.002
International Humic Substances Society (IHSS) (2019). Website of the IHSS. Available at http://humic-substances.org [verified 19 November 2019]

Kautenburger R, Hein C, Sander JM, Beck HP (2014). Influence of metal loading and humic acid functional groups on the complexation behavior of trivalent lanthanides analyzed by CE-ICP-MS. Analytica Chimica Acta 816, 50-59. doi:10.1016/J.ACA.2014.01.044

Kim JI, Buckau G, Li GH, Duschner H, Psarros N (1990). Characterization of humic and fulvic acids from Gorleben groundwater. Fresenius' Journal of Analytical Chemistry 338, 245-252. doi:10.1007/BF00323017

Koeppenkastrop D, De Carlo EH (1992). Sorption of rare-earth elements from seawater onto synthetic mineral particles: An experimental approach. Chemical Geology 95, 251-263. doi:10.1016/00092541(92)90015-W

Marsac R, Davranche M, Gruau G, Dia A (2010). Metal loading effect on rare earth element binding to humic acid: Experimental and modelling evidence. Geochimica et Cosmochimica Acta 74, 1749-1761. doi:10. 1016/J.GCA.2009.12.006

Marsac R, Davranche M, Gruau G, Bouhnik-Le Coz M, Dia A (2011). An improved description of the interactions between rare earth elements and humic acids by modeling: PHREEQC-Model VI coupling. Geochimica et Cosmochimica Acta 75, 5625-5637. doi:10.1016/J.GCA.2011.07.009

Marsac R, Davranche M, Gruau G, Dia A, Bouhnik-Le Coz M (2012). Aluminium competitive effect on rare earth elements binding to humic acid. Geochimica et Cosmochimica Acta 89, 1-9. doi:10.1016/J.GCA. 2012.04.028

Marsac R, Davranche M, Gruau G, Dia A, Pédrot M, Le Coz-Bouhnik M, Briant N (2013). Effects of Fe competition on REE binding to humic acid: Origin of REE pattern variability in organic waters. Chemical Geology 342, 119-127. doi:10.1016/J.CHEMGEO.2013.01.020

Marsac R, Davranche M, Morin G, Takahashi Y, Gruau G, Briant N, Dia A (2015). Effect of loading on the nature of the REE-humate complexes as determined by $\mathrm{Yb}^{3+}$ and $\mathrm{Sm}^{3+}$ LIII-edge EXAFS analysis. Chemical Geology 396, 218-227. doi:10.1016/J.CHEMGEO.2014.12.024

McKnight DM, Boyer EW, Westerhoff PK, Doran PT, Kulbe T, Andersen DT (2001). Spectrofluorometric characterization of dissolved organic matter for indication of precursor organic material and aromaticity. Limnology and Oceanography 46, 38-48. doi:10.4319/LO.2001. 46.1.0038

Nakada R, Waseda A, Okumura F, Takahashi Y (2016). Impact of the decarboxylation reaction on rare earth elements binding to organic matter: From humic substances to crude oil. Chemical Geology 420, 231-239. doi:10.1016/J.CHEMGEO.2015.11.021

Pearson RG (1963). Hard and Soft Acids and Bases. Journal of the American Chemical Society 85, 3533-3539. doi:10.1021/JA00905A001

Pourret O, Davranche M, Gruau G, Dia A (2007). Rare earth elements complexation with humic acid. Chemical Geology 243, 128-141. doi:10. 1016/J.CHEMGEO.2007.05.018

Pourret O, Davranche M, Gruau G, Dia A (2008). New insights into cerium anomalies in organic-rich alkaline waters. Chemical Geology 251, 120-127. doi:10.1016/J.CHEMGEO.2008.03.002

Quinn KA, Byrne RH, Schijf J (2006). Sorption of yttrium and rare earth elements by amorphous ferric hydroxide: Influence of solution complexation with carbonate. Geochimica et Cosmochimica Acta 70, 4151-4165. doi:10.1016/J.GCA.2006.06.014

Sonke JE, Salters VJM (2006). Lanthanide-humic substances complexation. I. Experimental evidence for a lanthanide contraction effect. Geochimica et Cosmochimica Acta 70, 1495-1506. doi:10.1016/J.GCA.2005.11.017

Tadini AM, Campanha MB, Moreira AB, Bisinoti MC (2013). Copper(II) and nickel (II) complexation capacity of dissolved organic matter from rivers of agricultural and urban areas in the state of São Paulo. Journal of the Brazilian Chemical Society 24, 1789-1797. doi:10.5935/0103-5053. 20130224

Takahashi Y, Châtellier X, Hattori KH, Kato K, Fortin D (2005). Adsorption of rare earth elements onto bacterial cell walls and its implication for REE sorption onto natural microbial mats. Chemical Geology 219, 53-67. doi:10.1016/J.CHEMGEO.2005.02.009

Takahashi Y, Yamamoto M, Yamamoto Y, Tanaka K (2010). EXAFS study on the cause of enrichment of heavy REEs on bacterial cell surfaces. 
Geochimica et Cosmochimica Acta 74, 5443-5462. doi:10.1016/J.GCA 2010.07.001

Tang J, Johannesson KH (2003). Speciation of rare earth elements in natural terrestrial waters: assessing the role of dissolved organic matter from the modeling approach. Geochimica et Cosmochimica Acta 67, 2321-2339. doi:10.1016/S0016-7037(02)01413-8

Vermeer AWP, van Riemsdijk WH, Koopal LK (1998). Adsorption of Humic Acid to Mineral Particles. 1. Specific and Electrostatic Interactions. Langmuir 14, 2810-2819. doi:10.1021/LA970624R
Zsolnay A, Baigar E, Jimenez M, Steinweg B, Saccomandi F (1999). Differentiating with fluorescence spectroscopy the sources of dissolved organic matter in soils subjected to drying. Chemosphere 38, 45-50. doi:10.1016/S0045-6535(98)00166-0 